\title{
Induction of tolerance to salt stress in soursop seedlings using hydrogen peroxide
}

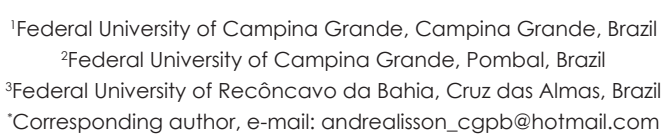

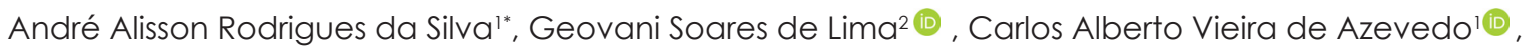

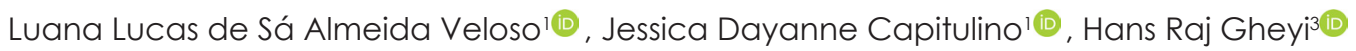

\begin{abstract}
The exogenous use of hydrogen peroxide is an alternative in the acclimatization of plants to salt stress due to the greater activity of antioxidant enzymes. In this perspective, this study aimed to evaluate the gas exchange and the growth of soursop seedlings under salt stress using hydrogen peroxide. The study was conducted under greenhouse conditions. The treatments were distributed in randomized blocks, in a $5 \times 2$ factorial arrangement, related to five levels of electrical conductivity of the irrigation water-ECW $\left(0.6,1.2,1.8,2.4\right.$, and $\left.3.0 \mathrm{dS} \mathrm{m}^{-1}\right)$ and two concentrations of hydrogen peroxide $-\mathrm{H}_{2} \mathrm{O}_{2}(0$ and $20 \mu \mathrm{M})$, with four replicates and two plants per plot. The effects of the treatments were evaluated by the variables of gas exchange and growth. The increase in water salinity negatively affected the gas exchange and the growth of the soursop seedlings. The gas exchange and growth variables presented deleterious effects caused by the salinity of the irrigation water, mitigated by the exogenous application of hydrogen peroxide at the concentration of $20 \mu \mathrm{M}$. The exogenous use of hydrogen peroxide at the concentration of $20 \mu \mathrm{M}$ can be used to induce salt tolerance in soursop seedlings.
\end{abstract}

Keywords: Annona muricata L., salinity, acclimatization

\section{Introduction}

Brazil has remained in recent years among the world's three largest fruit producers, second only to China and India (Reinhardt et al., 2018). According to the Anuário Brasileiro de Fruticultura (2018), the estimated production in 2018 was approximately 45.6 million tons, and the Northeast region is one of the main responsible for this production, especially due to the favorable edaphoclimatic conditions.

Among such fruits, soursop (Annona muricata L.) has been highlighted due to its food and nutritional properties and has also been studied for presenting pharmaceutical characteristics, being used in the treatment of inflammatory and diuretic diseases (Freitas et al., 2013; Bento et al., 2016). The Northeast region contributes with $80 \%$ of the national soursop production, the State of Bahia being the main producer (Lemos, 2014).

However, low rainfall and high evaporation rates are common in this region, naturally contributing to water restriction and to the increment in the salt concentrations of the groundwater (Veloso et al., 2018), which in most cases is the only water source employed in irrigation. environmental stresses in the entire world (Wu et al., 2018), whose deleterious effects on the crops occur due to the osmotic and ionic effects and, consequently, due to the oxidative stress (Wei et al., 2017). Salinity reduces the osmotic potential of the soil solution, limiting the availability of water for the plants, causing a reduction in the expansion of the leaf area and in the closing of stomata, damaging photosynthesis and inhibiting plant growth (Roy et al., 2014).

In this context, alternatives have been sought in order to attenuate the effects of salt stress on the crops. Among them, the exogenous application of hydrogen peroxide $\left(\mathrm{H}_{2} \mathrm{O}_{2}\right)$ has revealed to be promising in the acclimatization of the crops to salt stress (Bagheri et al., 2019; Silva et al., 2019). The exogenous application of hydrogen peroxide through spraying and/or pretreatment of the seeds, in low concentrations, provides a moderate stress condition that results in the accumulation of latent signs in different parts of the plant. Therefore, when a more severe stress condition occurs, the stored signs shall conduct to molecular adjustments, resulting in acclimatization mechanisms (Savvides et al., 2016).

Salt stress is one of the most frequent 
In view of the exposed, this study aimed to evaluate the gas exchanges and the growth of soursop seedlings under salt stress using hydrogen peroxide.

\section{Material and Methods}

The work was conducted in the period from June to November 2018, using plastic bags with capacity for $2 \mathrm{dm}^{3}$, in a greenhouse (70 15' 18' ' S latitude, 3552' 28', $W$ longitude, and average elevation of $550 \mathrm{~m}$ ) belonging to the Center of Technology and Natural Resources of the Federal University of Campina Grande (CTRN/UFCG), located in the municipality of Campina Grande, PB.

The treatments resulted from the combination of five levels of electrical conductivity of the irrigation water - ECW $\left(0.6 ; 1.2 ; 1.8 ; 2.4\right.$, and $\left.3.0 \mathrm{dS} \mathrm{m}^{-1}\right)$ and two concentrations of hydrogen peroxide $-\mathrm{H}_{2} \mathrm{O}_{2} \quad \mathrm{O} \mathrm{O}$ and $20 \mu \mathrm{M})$, in a $5 \times 2$ factorial scheme, distributed in a randomized block design with four replications and two plants per plot, totaling eighty plants.

The levels of electrical conductivity of the irrigation water were prepared by dissolving the salts $\mathrm{NaCl}, \mathrm{CaCl}_{2} \cdot 2 \mathrm{H}_{2} \mathrm{O}$, and $\mathrm{MgCl}_{2} \cdot 6 \mathrm{H}_{2} \mathrm{O}$ in the equivalent proportion of $7: 2: 1$, respectively, in local supply water (ECW $=1.10 \mathrm{dS} \mathrm{m}^{-1}$ ). This proportion is commonly found in the water sources used for irrigation in small properties in the Northeast region (Medeiros, 1992), based on the relation between the ECW and the concentration of salts $\left(\mathrm{mmol}_{\mathrm{c}} \mathrm{L}^{-1}=10^{*} \mathrm{CEa} \mathrm{dS} \mathrm{m}^{-1}\right)$ recommended by Rhoades et al. (2000). The level of $0.6 \mathrm{dS} \mathrm{m}^{-1}$ was obtained through the dilution of the local supply water into rainwater (ECW

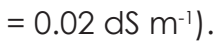

The filling of the plastic bags was performed by placing $2.6 \mathrm{~kg}$ of an air-dried substrate composed of soil $(84 \%)$, sand $(15 \%)$, and humus (1\%). The soil used in the experiment was an Entisol with sandy loam texture collected in the layer from 0-20 cm, from the rural area of the municipality of Lagoa Seca, PB, properly crushed and sieved. Its physical and chemical characteristics were determined according to the methodology proposed by Teixeira et al. (2017): exchangeable $\mathrm{Ca}^{2+}$, $\mathrm{Mg}^{2+}, \mathrm{Na}^{+}, \mathrm{K}^{+}, \mathrm{Al}^{3+}+\mathrm{H}^{+}=2.60 ; 3.66 ; 0.16 ; 0.22$, and 1.93 $\mathrm{cmol}_{\mathrm{c}} \mathrm{kg}^{-1}$, respectively; $\mathrm{pH}$ (soil : water, 1:2.5) = 5,9; ECse $=1.0 \mathrm{dS} \mathrm{m} \mathrm{m}^{-1}$; organic matter $=1.36 \mathrm{dag} \mathrm{kg}^{-1} ; \mathrm{P}=6.80 \mathrm{mg}$ $\mathrm{kg}^{-1}$; sand, silt, and clay $=732.9,142.1$, and $125.0 \mathrm{~g} \mathrm{~kg}^{-1}$, respectively; apparent density $=1,39 \mathrm{~kg} \mathrm{dm}^{-3}$; moisture at tensions of 33.42 and $1519.5 \mathrm{kPa}=11.98$ and $4.32 \mathrm{dag} \mathrm{kg}^{-1}$, respectively.

The seeds used in the experiment were obtained from fruits harvested in a commercial orchard in the municipality of Sousa, PB. The seeds were manually extracted; afterward, they were washed, air-dried and the dormancy breaking was performed through the distal section of the embryo, according to the methodology proposed by Mendonça et al. (2007).

Prior to the sowing, the seeds underwent a pretreatment with hydrogen peroxide $(20 \mu \mathrm{M})$, being soaked for a period of $36 \mathrm{~h}$. The seeds of the control treatment $(0 \mu M)$ were soaked in distilled water for the same time period. Afterward, three seeds of the soursop cv. Morada Nova were sown in plastic bag filled with substrate at a depth of three centimeters, distributed equidistantly. The thinning was performed 40 days after sowing (DAS) aiming to obtain one plant per bag, allowing the one with better vigor.

Prior to the sowing, the moisture content of the substrate was raised until reaching a maximum retention capacity, using water according to the treatment. After the sowing, the irrigation was performed daily, applying a volume of water in each plastic bag as to maintain the moisture of the substrate close to field capacity. The applied volume being determined according to the water requirement of the plants, estimated by the water balance through the subtraction of the drained volume from the applied volume in the previous irrigation. A leaching fraction of 0.10 (Ayers \& Westcot, 1999) was applied every 20 days aiming to avoid the excessive accumulation of salts in the root zone.

The fertilization with nitrogen, potassium, and phosphorus was performed in topdressing, observing the recommendation contained in Novais et al. (1991). $0.58 \mathrm{~g}$ of urea, $0.65 \mathrm{~g}$ of potassium chloride, and $1.56 \mathrm{~g}$ of monoammonium phosphate, equivalent to 100,150 , and $300 \mathrm{mg} \mathrm{kg}^{-1}$ of substrate of the $\mathrm{N}, \mathrm{K}_{2} \mathrm{O}$, and $\mathrm{P}_{2} \mathrm{O}_{5^{\prime}}$ respectively, were applied in topdressing in four equal applications via fertigation, at intervals of 15 days, with the first application performed 15 days after sowing (DAS). Aiming to meet the need for micronutrients, $2.5 \mathrm{~g}$ $\mathrm{L}^{-1}$ of ubyfol ( $\mathrm{N}-15 \% ; \mathrm{P}_{2} \mathrm{O}_{5}-15 \% ; \mathrm{K}_{2} \mathrm{O}-15 \%$; $\mathrm{Ca}-1 \%$; $\mathrm{Mg}-$ $1.4 \% ; \mathrm{S}-2.7 \%$; Zn - 0.5\%; B - 0.05\%; Fe - 0.5\%; Mn - 0.05\%; Cu - 0.5\%; Mo - 0.02\%) was applied on the adaxial and abaxial surfaces of the leaves, at $60,75,90,105,120$, and 135 DAS.

The application of the $\mathrm{H}_{2} \mathrm{O}_{2}$ was manually performed at 5 h00 p.m., in the respective concentrations, at $80,95,110$, and 145 DAS, by spraying the abaxial and adaxial surfaces of the leaves in order to obtain a complete wetting of the leaf area, with the aid of a sprinkler. 
The following variables were measured at 110 days after sowing (DAS): gas exchange through stomatal conductance ( $\mathrm{mol} \mathrm{H} \mathrm{H}_{2} \mathrm{O} \mathrm{m}^{-2} \mathrm{~s}^{-1}$ ), transpiration (mmol $\mathrm{H}_{2} \mathrm{O}$ $\left.\mathrm{m}^{-2} \mathrm{~s}^{-1}\right), \mathrm{CO}_{2}$ assimilation rate ( $\mu \mathrm{mol} \mathrm{m}^{-2} \mathrm{~s}^{-1}$ ), and internal

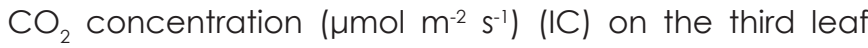
from the apex, employing irradiation of $1200 \mu \mathrm{mol}$ photons $\mathrm{m}^{-2} \mathrm{~s}^{-1}$ and an airflow rate of $200 \mathrm{~mL} \mathrm{~min}^{-1}$, by using an "LCProt" portable photosynthesis measurement equipment manufactured by ADC BioScientific Ltda .

The effects of the ECW levels and the concentrations of hydrogen peroxide on the growth of seedlings of the soursop cv. Morada Nova were analyzed at 145 DAS by the plant height (PH), stem diameter (SD), number of leaves (NL), and leaf area (LA).

The plant height $(\mathrm{cm})$ was determined using as reference the distance from the plant base to the insertion of the apical meristem; the DC ( $\mathrm{mm}$ ) was measured at 2 $\mathrm{cm}$ from the base of the plant, and the number of leaves was obtained by counting all the fully expanded leaves with minimum length of $3 \mathrm{~cm}$.

The leaf area $\left(\mathrm{cm}^{2}\right)$ was determined according to the recommendation of Almeida et al. (2006), considering Equation 1:

$$
L A=\sum 5.71+0.647 X
$$

Where:

LA - leaf area $\left(\mathrm{cm}^{2}\right)$; and,

$X$ - product of the length $(\mathrm{cm})$ and width $(\mathrm{cm})$ of the leaf.

The obtained data were evaluated through analysis of variance at the level of 0.05 and 0.01 of probability, performing a linear and quadratic polynomial regression for the factor salt levels, in the case of significance. In the $\mathrm{H}_{2} \mathrm{O}_{2}$ factor, Tukey's test was applied for the comparison of the means at a 0.05 level of probability, using the SISVAR-ESAL statistical software (Ferreira, 2014).

\section{Results and Discussion}

The interaction between the salinity of the irrigation water (NS) and the concentrations of hydrogen peroxide $\left(\mathrm{H}_{2} \mathrm{O}_{2}\right)$ significantly influenced the variables: stomatal conductance (gs), transpiration rate (E), $\mathrm{CO}_{2}$ assimilation rate (A), and internal $\mathrm{CO}_{2}$ concentration ( $\mathrm{Cl}$ ) of the seedlings of soursop cv. Morada Nova at 110 days after sowing.
As depicted in Figure 1A, the increase in the electrical conductivity of the irrigation water negatively affected the stomatal conductance of the soursop cv. Morada Nova in spite of the exogenous application of hydrogen peroxide. According to the means comparison test, a reduction of $59.67 \%$ in the gs $\left(0.037 \mathrm{~mol} \mathrm{H}_{2} \mathrm{O} \mathrm{m} \mathrm{m}^{-2} \mathrm{~s}^{-1}\right)$ was noted in the control plants $(0 \mu \mathrm{M})$ irrigated with the highest salinity water $\left(3.0 \mathrm{dS} \mathrm{m}^{-1}\right)$ in relation to the lowest salt level $\left(0.6 \mathrm{dS} \mathrm{m}^{-1}\right)$. Such a response might be caused by the osmotic effects of salinity in the root zone of the plants, minimizing the water losses to the atmosphere and maintaining a high cell water potential (Sousa et al., 2016).

In spite of the reduction in the gs with the increment in water salinity, it can be noted that the application of hydrogen peroxide in the concentration of $20 \mu \mathrm{M}$ promoted a higher stomatal conductance when compared to the control treatment, for all salt levels. According to Azevedo Neto et al. (2005), the exogenous application of $\mathrm{H}_{2} \mathrm{O}_{2}$ before the exposure to salt stress induces the tolerance to salinity through the activation of the defense system of antioxidant enzymes, such as the superoxide dismutase (SOD, EC 1.15.1.1), catalase (CAT, EC 1.11.1.6), guaiacol peroxidase (GPX, EC 1.11.1.7), and ascorbate peroxidase (APX, EC 1.11.1.11).

Based on Figure 1B, it can be observed that the interaction between the factors salinity of the irrigation water and concentrations of hydrogen peroxide interfered in the transpiration rate of the soursop plants. The plants that were not treated with $\mathrm{H}_{2} \mathrm{O}_{2}(0 \mu \mathrm{M})$ had a

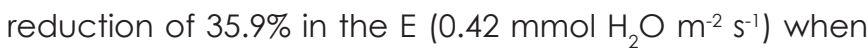
irrigated with the highest salinity water $\left(3.0 \mathrm{dS} \mathrm{m}^{-1}\right)$ in relation to those of lowest salt level $\left(0.6 \mathrm{dS} \mathrm{m}^{-1}\right)$. However, it can be noted that the plants that received the treatment with hydrogen peroxide (20 $\mu \mathrm{M})$ obtained higher values of E compared to the control treatment, for all salt levels. However, a reduction of $36.72 \%\left(0.47 \mathrm{mmol} \mathrm{H}_{2} \mathrm{O} \mathrm{m}^{-2} \mathrm{~s}^{-1}\right)$ is verified in the transpiration rate of the soursop plant when irrigated with the highest salinity water, compared to the lowest salinity water.

Similar results were obtained by Gondim et al. (2013) when evaluating the effect of $\mathrm{H}_{2} \mathrm{O}_{2}(\mathrm{O}$ and 10 $\mathrm{mM}$ ) in maize plants under salt stress, verifying that the transpiration rate in the plants that were treated with hydrogen peroxide was higher compared to the plants of the control treatment (0 $\mathrm{mM})$. 

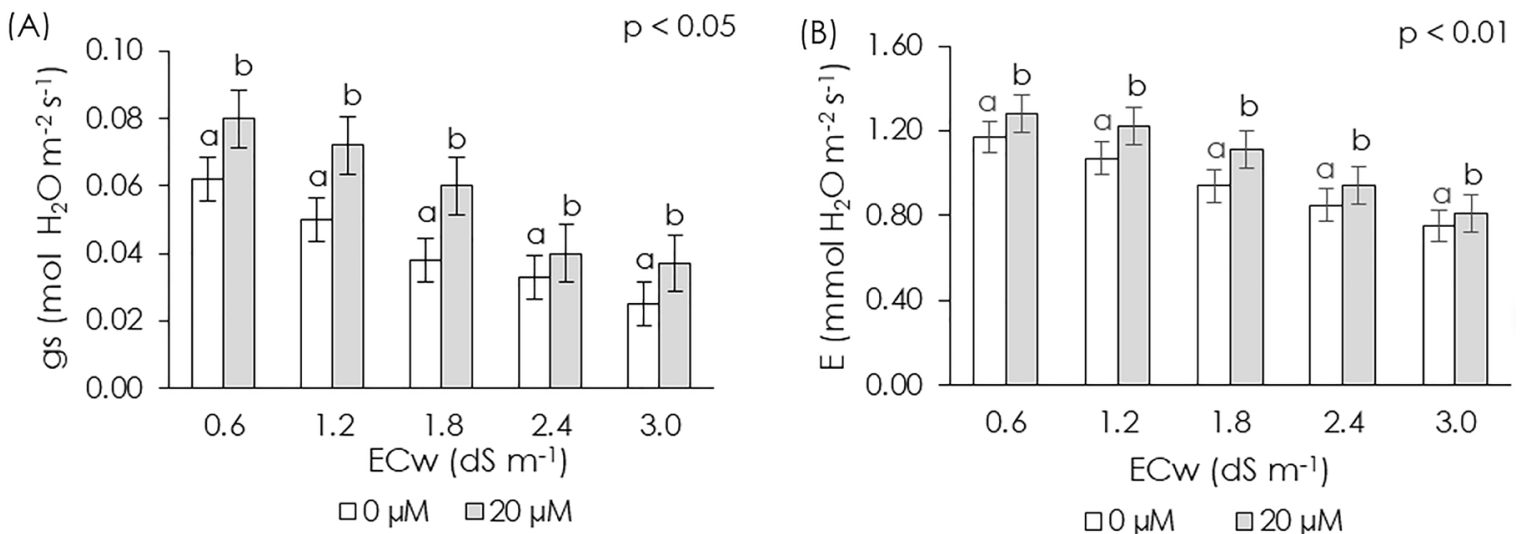

Figure 1. Stomatal conductance - gs (A) and transpiration rate - E (B) as a function of the interaction between the electrical conductivity of the irrigation water - ECW and the concentrations of hydrogen peroxide $\mathrm{H}_{2} \mathrm{O}_{2}$, at 110 days after sowing. Observation: For the same level of water salinity, means followed by same letter do not differ significantly at 0.05 level of probability by Tukey test

The beneficial effect of the hydrogen peroxide on the transpiration rate might be related to its function as a signalizing molecule, acting in the regularization of several pathways, including responses to salt stress (Baxter et al., 2014). According to Carvalho et al. (2011) the hydrogen peroxide, when applied in low concentrations on the plants, induces the defense system of antioxidant enzymes, which act by reducing the deleterious effects of salinity.

When studying the interaction of the salinity of the irrigation water with the concentrations of hydrogen peroxide on the $\mathrm{CO}_{2}$ assimilation rate of the soursop cv. Morada Nova, it is verified that according to the mean comparison test (Figure 2A) the increase in the salinity of the irrigation water reduced the $\mathrm{CO}_{2}$ assimilation rate of the control plants $(0 \mu \mathrm{M})$. However, under the concentration

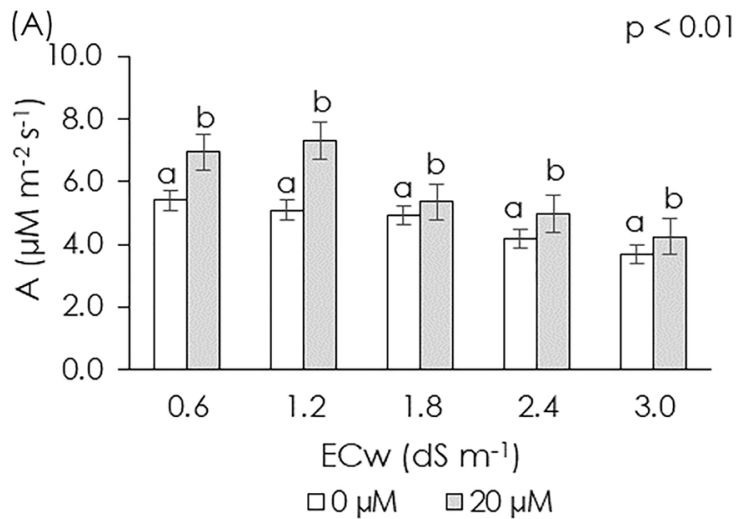

of $20 \mu \mathrm{M}$ of $\mathrm{H}_{2} \mathrm{O}_{2}$, it is seen that the deleterious effect on the assimilation rate caused by the increment in the water salinity is mitigated, verifying through the mean comparison test (Figure 2A) that the concentration of 20 $\mu \mathrm{M}$ of $\mathrm{H}_{2} \mathrm{O}_{2}$, associated to the water salinity level of $1.2 \mathrm{dS}$ $\mathrm{m}^{-1}$ resulted in the highest $\mathrm{CO}_{2}$ assimilation rate $(7.31 \mu \mathrm{M}$ $\left.\mathrm{m}^{-2} \mathrm{~s}^{-1}\right)$.

The induction of tolerance through the exogenous application of $\mathrm{H}_{2} \mathrm{O}_{2}$ on the $\mathrm{CO}_{2}$ assimilation rate might occur due to the modulation of the detoxification processes of reactive oxygen species (Wang et al., 2014) and also through the regulation of the stomata (Gondim et al., 2013), since the gs (Figure 1A) in the plants subjected to the hydrogen peroxide was higher compared to the plants of the control treatment.

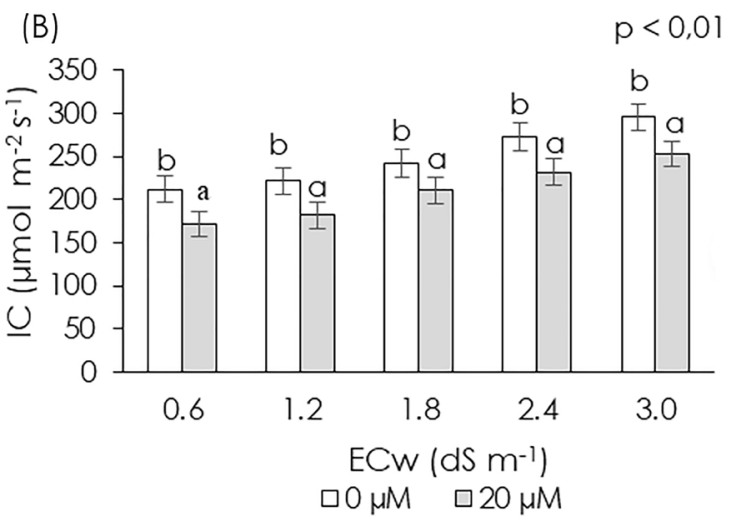

Figure 2. $\mathrm{CO}_{2}$ assimilation rate - $\mathrm{A}(\mathrm{A})$ and internal concentration of $\mathrm{CO}_{2}-\mathrm{IC}(\mathrm{B})$ as a function of the interaction between the electrical conductivity of the irrigation water - ECW and the concentrations of hydrogen peroxide $\left(\mathrm{H}_{2} \mathrm{O}_{2}\right)$, at 110 days after sowing. Observation: For the same level of water salinity, means followed by same letter do not differ significantly at 0.05 level of probability by Tukey test

With regard to the internal concentration of $\mathrm{CO}_{2}$ (IC) of the soursop cv. Morada Nova, it can be verified that the increase in the ECW linearly increased the IC, in spite of the application of hydrogen peroxide, and according to the mean comparison test (Figure 2B), an increase of $31.53 \%$ can be noted in the IC of the control treatment plants $(0 \mu \mathrm{M})$ when irrigated with the highest salinity water, compared to the one with lowest salt level. As for the plants subjected to the treatment with $\mathrm{H}_{2} \mathrm{O}_{2}(20$ $\mu \mathrm{M})$, they obtained an increase of $42.7 \%$ in the IC when irrigated with the highest salinity water in relation to the lowest salt level. According to Silva et al. (2011), the increase in water salinity might result in the elevation of the IC concentration in the leaves, which causes a toxic 
effect, reducing the carboxylation efficiency of Rubisco, the enzyme responsible for carbon fixation, resulting in an increase in the internal concentration of $\mathrm{CO}_{2}$ in the leaves.

Similar results were observed by Silva et al. (2018) in the soursop cv. Nordestina irrigated with water with electrical conductivity varying from 0.5 to $3.5 \mathrm{dS} \mathrm{m}^{-1}$, verifying a linear increase of $12.49 \%$ per unit increment of the ECW in the internal concentration of $\mathrm{CO}_{2}$.

The plants pre-treated with $20 \mu \mathrm{M}$ of $\mathrm{H}_{2} \mathrm{O}_{2}$ and exposed to salt stress presented reductions in the IC (Figure 2B) when compared to those that did not receive the treatment with $\mathrm{H}_{2} \mathrm{O}_{2}(0 \mu \mathrm{M})$; consequently, the plants subjected to the $\mathrm{H}_{2} \mathrm{O}_{2}$ obtained a higher $\mathrm{CO}_{2}$ assimilation rate (Figure 2A), indicating that the concentration of $20 \mathrm{M}$ of $\mathrm{H}_{2} \mathrm{O}_{2}$ induced the tolerance to salt stress in the soursop plants. According to Forman et al. (2010) the pre-exposure of the plants to moderate stresses or signalizing metabolites, such as the $\mathrm{H}_{2} \mathrm{O}_{2}$, might result in a metabolic signaling in the cell, increase of metabolites and/or antioxidant enzymes and, consequently, it results in a better physiological performance when the plant is exposed to more severe stress conditions.

The interaction between the salinity of the irrigation water and the concentrations of hydrogen peroxide also influenced the variables: plant height $\mathrm{PH}$ ), stem diameter (SD), and number of leaves (NL). The leaf area was only affected by the salinity of the irrigation water.
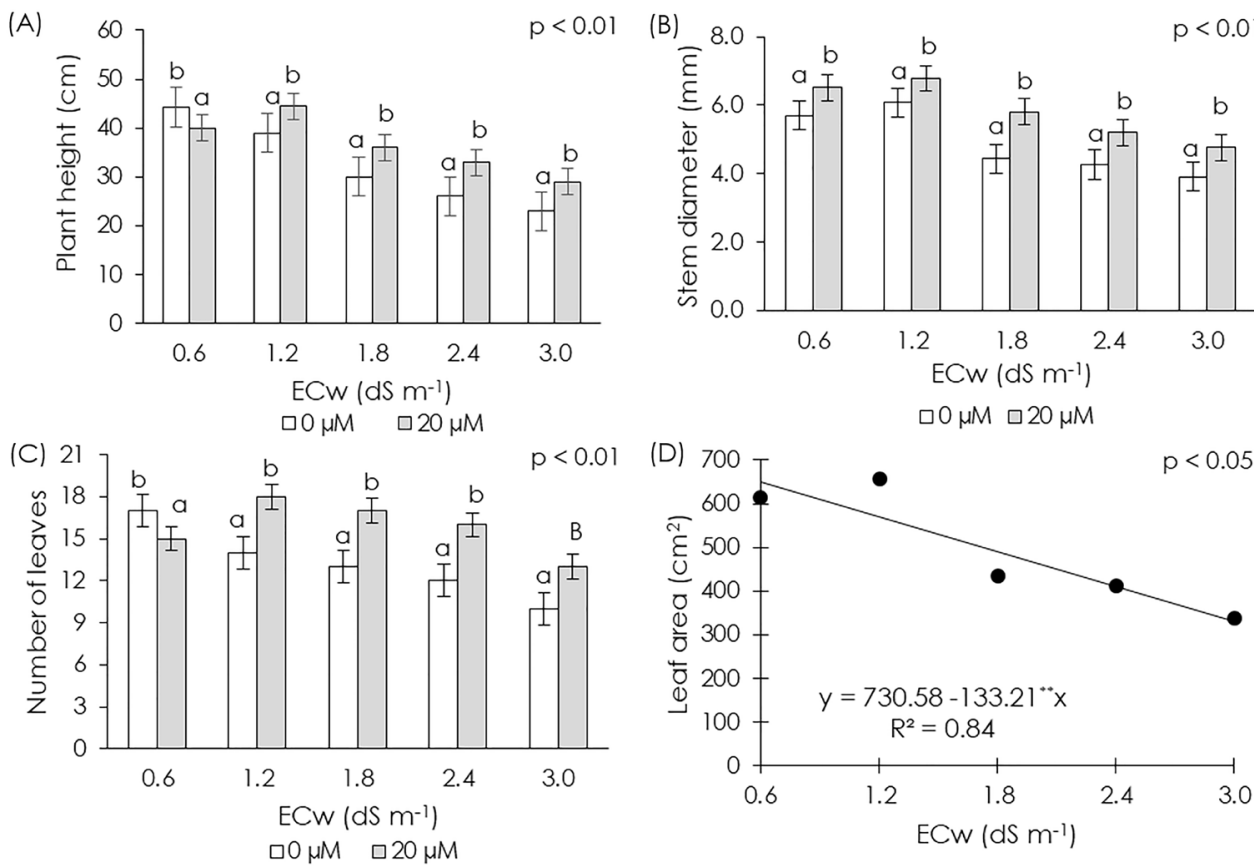

Figure 3. Plant height - $\mathrm{PH}(\mathrm{A})$, stem diameter - SD (B), and number of leaves - NL (C) as a function of the interaction between the electrical conductivity of the irrigation water - ECW and the concentrations of hydrogen peroxide $\left(\mathrm{H}_{2} \mathrm{O}_{2}\right)$, and leaf area - LA (D) as a function of the ECW. Observation: For the same level of water salinity, means followed by same letter do not differ significantly at 0.05 level of probability by Tukey test 
In this study, it must be emphasized that all gas exchange parameters were less affected by salinity in the plants previously treated with $\mathrm{H}_{2} \mathrm{O}_{2}$ in the concentration of $20 \mu \mathrm{M}$. In this manner, the increase in the stomatal conductance, transpiration rate, and $\mathrm{CO}_{2}$ assimilation rate observed in the plants subjected to the $\mathrm{H}_{2} \mathrm{O}_{2}$ interfered positively, promoting higher means for plant height, stem diameter, and the number of leaves of the soursop cv. Morada Nova when exposed to water salinity.

The positive effect of the hydrogen peroxide on the PH, SD, and NL of the soursop may be attributed to the induction of tolerance of the plants to salt stress, which occurs through the modulation of physiological and metabolic processes, such as photosynthesis, accumulation of proline, and detoxification of reactive oxygen species, thus improving the growth and development of the plants (Hossain et al., 2015).

The beneficial effects of the exogenous application of hydrogen peroxide on the growth variables were also reported by Ashfaque et al. (2014) in wheat plants (Triticum aestivum L.) under salt stress. In the study, it was verified that the application of 50 or $100 \mu \mathrm{M}$ of $\mathrm{H}_{2} \mathrm{O}_{2}$ reduced the severity of the salt stress, with reductions in the levels of $\mathrm{Na}^{+}$and $\mathrm{Cl}^{-}$ions, besides increasing the content of proline and the assimilation of nitrogen.

By analyzing the regression equation (Figure 3D) referring to the leaf area (LA), the linear model indicates a decrease of $18.23 \%$ per unit increase of the $\mathrm{ECW}$, that is, a reduction of $49.14 \%\left(319.70 \mathrm{~cm}^{2}\right)$ in the plants irrigated

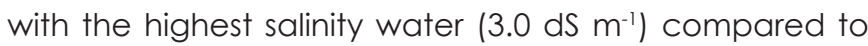
those of lowest salinity level $\left(0.6 \mathrm{dS} \mathrm{m}^{-1}\right)$.

The reduction in the leaf area is related to the accumulation of salts in the soil, which negatively affects water absorption by the plants, compromising the photosynthetic and metabolic processes, resulting in the reduction of the photosynthetic apparatus (Bezerra ef al., 2018). Furthermore, the decrease in the leaf area is a mechanism adopted by the plant to protect itself and/or acclimate to the salt stress condition, since the reduction in the LA minimizes the water losses through transpiration and maintains a high cell water potential (Lima et al., 2018). Similar results were observed by Veloso et al. (2018) while studying the effect of salt stress and nitrogen fertilization on the formation of seedlings of the soursop $c v$. Morada Nova, verifying a reduction in the leaf area with the increment in the salinity of the irrigation water.

\section{Conclusions}

The salinity level of the irrigation water from 0.6 $\mathrm{dS} \mathrm{m}^{-1}$ reduces gas exchanges and the growth of plants of the soursop cv. Morada Nova. The gas exchanges and the growth of the soursop cv. Morada Nova have deleterious effects caused by the salinity of the irrigation water, which are mitigated by the exogenous application of hydrogen peroxide in the concentration of $20 \mu \mathrm{M}$. The exogenous application of hydrogen peroxide in the concentration of $20 \mu \mathrm{M}$ can be used in the induction of tolerance to salt stress in soursop plants.

\section{References}

Almeida, G., Santos, J., Zucoloto, M., Vicentini, V., Moraes, W., Bregoncio, I., Coelho, R. 2006. Estimativa de área foliar de graviola (Annona muricata L.) por meio de dimensões lineares do limbo foliar. Revista UNIVAP 1: 1035-1037.

Ayers, R.S., Westcot, D.W. 1999. A qualidade de água na agricultura. 2.ed. UFPB, Campina Grande, Brasil. 153 p. (FAO Irrigação e Drenagem, 29).

Anuário Brasileiro de Fruticultura. 2018. Brazilian fruits yearbook. Gazeta, Santa Cruz do Sul, Brasil. 88 p.

Ashfaque, F., Khan, M.I.R., Khan, N.A. 2014. Exogenously applied $\mathrm{H}_{2} \mathrm{O}_{2}$ promotes proline accumulation, water relations, photosynthetic efficiency and growth of wheat (Triticum aestivum L.) under salt stress. Annual Research \& Review in Biology 4: 105-120.

Azevedo Neto, A.D., Prisco, J.T., Enéas-Filho, J., Medeiros, J.V.R., Gomes-Filho, E. 2005. Hydrogen peroxide pretreatment induces salt-stress acclimation in maize plants. Journal of Plant Physiology 162: $1114-1122$.

Bagheri, M., Gholami, M., Baninasab, B. 2019. Hydrogen peroxide-induced salt tolerance in relation to antioxidant systems in pistachio seedlings. Scientia Horticulturae 243: 207-213.

Baxter, A., Mittler, R., Suzuki, N. 2014. EROS as key players in plant stress signalling. Journal of Experimental Botany 65: 1229-1240.

Bento, E.B., Monteiro, Á.F., Lemos, I.C.S., Brito Junior, F.E., Oliveira, D.R., Menezes, I.R.A., Kerntopf, M.R. 2016. Estudio etnofarmacológico comparativo en la región del Araripe de la Annona muricata L. (Graviola). Revista Cubana de Plantas Medicinales 21: 9-19.

Bezerra, I.L., Nobre, R.G., Gheyi, H.R., Souza, L.D.P., Pinheiro, F.W., Lima, G.S.D. 2018. Morphophysiology of guava under saline water irrigation and nitrogen fertilization. Revista Brasileira de Engenharia Agrícola e Ambiental 22: 32-37.

Carvalho, F.E.L., Lobo, A.K.M., Bonifacio, A., Martins, M.O., Lima Neto, M., Silveira, J.A.G. 2011. Aclimatação ao estresse salino em plantas de arroz induzida pelo prétratamento com $\mathrm{H}_{2} \mathrm{O}_{2}$. Revista Brasileira de Engenharia Agrícola e Ambiental 15: 416-423.

Ferreira, D.F. 2014. Sisvar: A guide for its bootstrap procedures in multiple comparisons. Ciência e Agrotecnologia 38: 109-112. 
Forman, H.J., Maiorino, M., Ursini, F. 2010. Signaling functions of reactive oxygen species. Biochemistry 49: 835-842.

Freitas, A.L.G.E., Vilasboas, F.S., Pires, M.M., São José, A.R. 2013. Caracterização da produção e do mercado da graviola (Annona muricata L.) no Estado da Bahia. Informações Econômicas 43: 23-34.

Gondim, F.A., Miranda, R.D.S., Gomes-Filho, E., Prisco, J.T. 2013. Enhanced salt tolerance in maize plants induced by $\mathrm{H}_{2} \mathrm{O}_{2}$ leaf spraying is associated with improved gas exchange rather than with non-enzymatic antioxidant system. Theoretical and Experimental Plant Physiology 25: 251-260.

Hossain, M.A., Bhattacharjee, S., Armin, S.M., Qian, P., Xin, W., Li, H.Y., Tran, L.S.P. 2015. Hydrogen peroxide priming modulates abiotic oxidative stress tolerance: insights from ROS detoxification and scavenging. Frontiers in Plant Science 6: 1-19.

Lemos, E.E.P. 2014. A produção de anonáceas no Brasil. Revista Brasileira de Fruticultura 36: 77-85.

Lima, G.S de., Dias, A.S., Gheyi, H.R., Soares, L.A.A., Andrade, E., Gonçalves, M. 2018. Saline water irrigation and nitrogen fertilization on the cultivation of colored fiber cotton. Revista Caatinga 31: 151-160.

Medeiros, J.F. 1992. Qualidade de água de irrigação e evolução da salinidade nas propriedades assistidas pelo GAT nos Estados de RN, PB e CE. 173f. (Dissertação de Mestrado) - Universidade Federal da Paraíba, Campina Grande, Brasil.

Mendonça, V., Ramos, J.D., Pio, R., Gontijo, T.C.A., Tosta, M.S. 2007. Superação de dormência e profundidade de semeadura de sementes de gravioleira. Revista Caatinga 20: 73-78.

Novais, R.F., Neves J.C.L., Barros N.F. 1991. Ensaio em ambiente controlado. In: Oliveira, A.J. (ed.) Métodos de pesquisa em fertilidade do solo. Embrapa-SEA, Brasília, Brasil. 392 p.

Reinhardt, D.H.R., Bartolomeu, D.P., Souza, F.V.D., Carvalho, A.C.P.P.D., Pádua, T. R.P.D., Junghans, D.T. Matos, A.P.D. 2018. Advances in pineapple plant propagation. Revista Brasileira de Fruticultura 40: 1-22.

Rhoades, J.D., Kandiah, A., Mashali, A.M. 2000. Uso de águas salinas para produção agrícola. UFPB, Campina Grande, Brasil. 117 p. (FAO Irrigação e Drenagem, 48).

Roy, S.J., Negrão, S., Tester, M. 2014. Salt resistant crop plants. Current Opinion in Biotechnology 26: 115-124.

Savvides, A., Ali, S., Tester, M., Fotopoulos, V. 2016. Chemical priming of plants against multiple abiotic stresses: mission possible?. Trends in Plant Science 21: 329340.

Silva, A.A.R., Lima, G.S., Azevedo, C.A.V., Veloso, L.L.S.A., Gheyi, H.R., Soares, L.A.A. 2019. Salt stress and exogenous application of hydrogen peroxide on photosynthetic parameters of soursop. Revista Brasileira de Engenharia
Agrícola e Ambiental 23: 257-263.

Silva, E.M., Lima, G.S., Gheyi, H.R., Nobre, R.G., Sá, F.V.S., Souza, L.D.P. 2018. Growth and gas exchanges in soursop under irrigation with saline water and nitrogen sources. Revista Brasileira de Engenharia Agrícola e Ambiental 22: 776-781.

Silva, E.N., Ribeiro, R.V., Ferreira, S.L., Viégas, R.A., Silveira, J.A.G. 2011. Salt stress induced damages on the photosynthesis of physic nut young plants. Scientia Agricola 68: 62-68.

Sousa, J.R., Gheyi, H.R., Brito, M.E.B., Xavier, D.A., Furtado, G.D.F. 2016. Impact of saline conditions and nitrogen fertilization on citrus production and gas exchanges. Revista Caatinga 29: 415-424.

Taiz, L., Zeiger, E., Møller, I.M., Murphy, A. 2017. Fisiologia e desenvolvimento vegetal. 6.ed. Artmed, Porto Alegre, Brasil. $858 \mathrm{p}$.

Teixeira, P.C., Donagemma, G.K., Fontana, A., Teixeira, W.G. 2017. Manual de métodos de análise de solo. 3.ed. Embrapa Solos, Brasília, Brasil. 573 p.

Veloso, L.L.D.S.A., Nobre, R.G., Souza, L.P., Gheyi, H.R., Cavalcante, I.T.S., Araujo, E.B.G., Silva, W.L. 2018. Formation of soursop seedlings irrigated using waters with different salinity levels and nitrogen fertilization. Bioscience Journal 34: 151-160.

Wang, Y., Zhang, J., Li, J.L., Ma, X.R. 2014. Exogenous hydrogen peroxide enhanced the thermotolerance of Festuca arundinacea and Lolium perenne by increasing the antioxidative capacity. Acta Physiologiae Plantarum 36: $2915-2924$.

Wei, Y., Xu, Y., Lu, P., Wang, X., Li, Z., Cai, X., Liu, F. 2017. Salt stress responsiveness of a wild cotton species (Gossypium klotzschianum) based on transcriptomic analysis. Plos One 12: 1-25.

Wu, J., Shu, S., Li, C., Sun, J., Guo, S. 2018. Spermidinemediated hydrogen peroxide signaling enhances the antioxidant capacity of salt-stressed cucumber roots. Plant Physiology and Biochemistry 128: 152-162.

Conflict of Interest Statement: The authors declare that the research was conducted in the absence of any commercial or financial relationships that could be construed as a potential conflict of interest.

All the contents of this journal, except where otherwise noted, is licensed under a Creative Commons Attribution License attribuition-type BY. 